\title{
The Primacy of Philosophy for Effective Learning
}

\author{
Beth Edmondson, Monash University Gippsland Campus, Victoria, \\ Australia \\ Debra Manning, Monash University Gippsland Campus, Victoria, \\ Australia
}

\begin{abstract}
This paper argues that philosophy matters more than platforms - and even learning object design - in effective online education. Much of the literature concerning quality, experiential learning and associated pedagogical issues for online learning falls short of examining the fundamental role of educational philosophy. While questions of platform and design are also relevant, they represent second order considerations in the overall scheme of effective learning. It seems likely that this gap helps to explain why meaningful online and e-learning pedagogies have not flourished or matured alongside the growth of online learning.
\end{abstract}

Keywords: Educational Philosophy, Effective Pedagogy

$\mathrm{T}$

HIS PAPER ARGUES that questions of philosophy ought to be more centrally regarded in developing, designing and delivering online curriculum and learning experiences. Educational philosophy sits at the heart of universities as social institutions and might therefore be expected to inform their course and curriculum design, even as they move to expand their adoption of the latest technologies (Jordan, Carlile and Stack 2008; Palloff and Pratt 2007). These issues are important for university scholarship as well as the extent and depth of students' learning experiences. However, matters of educational philosophy frequently seem neglected in favour of assessing the relative merits of selected online learning platforms.

'The philosophy of education can be defined as the study of the purposes, processes, nature and ideals of education', revealing the importance of contemplating the roles of universities and their approaches to learning within their broader social contexts (Jordan, Carlile and Stack 2008: 6). This is consistent with Maxcy's view that 'the philosophy of education' concerns 'a personal set of problem-solving skills' (Maxcy 1978: iv). Nigel Tubbs (2005:183) extends this view by evocatively employing the metaphor of 'the broken middle' to draw attention to the relationship between education and philosophy in the inevitably, 'contradictory' experiences of teaching. The concept of the 'broken middle', drawn from Gillian Rose (1996 cited in Tubbs 2005:194), challenges us to eschew dualistic thinking concerning philosophy and education in our teaching practice, and so resist the urge to 'fix the broken middle'. Seeking to repair a dualistic relationship between philosophy and education in order to suppress the difficulties we experience in the 'broken middle' of our teaching achieves little beyond reducing our discomfort. More fruitful experiences lie in accommodating the 'broken middle' and our discomfort with its unreconciled tensions, in order to explore the fuller dimensions of education and philosophy.

The International Journal of Learning

Volume 16, Number 10, 2009, http://www.Learning-Journal.com, ISSN 1447-9494

(C) Common Ground, Beth Edmondson, Debra Manning, All Rights Reserved, Permissions:

cg-support@commongroundpublishing.com 
Educational practitioners who demonstrate self-awareness and philosophically framed approaches might then favour one side of the dualism of philosophy and education without any particular intention to do so (Tubbs 2005:194/5). Instead, Tubbs urges us to engage in speculative thinking to explore how educational philosophy 'speaks to the contradictory experiences of teachers' practice' (Tubbs 2005:197). Our approach in this paper is to maintain a speculative approach in exploring what we perceive as the 'broken middle', the gap between educational philosophy and the use of on-line learning platforms in university education. Without taking sides, we seek to strengthen the relationship between philosophy, education and online teaching practice.

We maintain that philosophical approaches and conceptual models regarding the roles and purposes of learning work to shape the nature of the learning that subsequently occurs - and the manner in which it is ultimately utilised. Most importantly, they inform the range and processes of knowledge and skills acquisition, including capacities for cognitive and intellectual social engagement. Therefore, decisions concerning whether, when and how to adopt online learning platforms ought to proceed on the basis of re-examining first principles regarding the value and purpose of university education. Since modern universities have largely been founded on the basis that higher education is transformative, their incorporation of new technologies and responsiveness to changed social conditions are to be expected (Williams, Paprock and Covington 1999; Simpson 2002; Moore, Fowler and Watson 2007). Indeed, their adoption of new technologies, including those utilised in online learning, are important to their contemporary roles. However, other factors, such as competition for market share, government funding for student places, and status often seem to drive the adoption of new technologies, with little regard for educational philosophy (Bowles 2004; Hartman 2008: 25; Bok 2006).

Much of the literature concerning online learning tends to engage directly with design and curriculum issues, including educational quality (Bell, Bush, Nicholson, O'Brien and Tran 2002; Boettcher 2004; Reid 2005). Some of the online learning literature also examines the pedagogical value of experiential learning (Alexander and Boud 2002; Coomey and Stephenson 2002; Smith 2008). Much of this literature, however, falls short of examining the fundamental role of educational philosophy. Instead of examining basic questions concerning the overall value, role and purpose of skills and knowledge, courses, programs and modes of educational opportunities, a sizeable proportion of the literature tends to amount to one form or another of a 'how to' guide or toolbox approach to online teaching and learning (Hartman 2008: 25; Duffy and Kirkley 2004). To the extent that issues of educational philosophy arise, they tend to be considered via the lens of particular approaches to learning wherein they examine the relative merits of constructivist accounts, student-centred or experiential learning. The educational philosophical dimensions of examining particular learning models, such as 'what are the social or knowledge community advantages of learning X content by Y method?' tend not to be addressed.

Alternatively, the literature seeks to examine the ways in which new pedagogical challenges might be identified in the altered learning environment of online and multimodal delivery. Sometimes, it also examines the manner in which online learning experiences and environments replicate or extend familiar learning models (Hase and Ellis 2002; Moore, Fowler and Watson 2007). Most commonly, online learning contexts are examined as sources of experiential learning and/or contexts in which student-centred (or other outcomes focused learning) can be achieved (Moore, Fowler and Watson 2007; Lapadat 2007; Parchoma 2003; Woodman, 
Milankovich-Atkinson, Sadler and Murphy 2002). Again, the philosophical or meta-pedagogical dimensions tend to be set aside.

It is then only infrequently that questions of educational philosophy continue to be addressed. Rarely are the altered learning and skills bases that constitute online learning environments examined for their ability to meet meta-pedagogical requirements. Equally rare are examinations of their impacts upon broader learning communities or contributions to social fabric and visions of human societies. At best, matters of educational philosophy tend to remain implicit in the assumptions that underpin online learning research and scholarship.

This does not mean that questions of pedagogy or learning design are entirely neglected, but it does mean that analysis of the importance of educational philosophy for online learning is neither systematically nor universally incorporated into ongoing scholarship (Hase and Ellis 2002; Stacey and Wiesenberg 2007; Goodyear and Ellis 2008). Many of the divisions and diverse arguments concerning the value or relative merits of online learning reflect preexisting debates concerning educational philosophies (Jordan, Carlile and Stack 2008: 6) This may well be partly a consequence of the momentum generated by leading educational providers seeking to establish their credentials in adopting new technologies. For many universities, these new technologies constituted 'a driving force that should be used for the benefit of education', reflecting both genuine interest in new knowledge and skills potential and also changing market expectations in relation to graduate attributes (Williams, Paprock and Covington 1999:20). To some extent, the very existence of new technologies created expectations of their potential roles in teaching and learning. Many universities readily accepted expectations of their need to utilize new technologies in teaching, administration and research, and some cultivated such expectations as part of their broader efforts to secure market share and educational relevance early in the $21^{\text {st }}$ century (Owen and Aworuwa 2004:339; Williams, Paprock and Covington 1999:21; Bowles 2004:10). Their active adoption of new learning technologies was not idiosyncratic to the new technologies of the late $20^{\text {th }}$ century but rather consistent with the historical roles of universities in seeking and exploring new fields of knowledge and education.

We argue that university educators make better choices concerning their adoption and use of online technologies and learning objects when they attend first to questions of educational philosophy (Jordan, Carlile and Stack 2008; Goodyear and Ellis 2008). This might seem an unnecessary matter for discussion since it could be claimed that many of those choosing online instruments, platforms or tools for use are implicitly reflecting philosophical predispositions. For instance, it might be argued that innovative teachers can prove their 'innovativeness' by utilising online learning objects, or 'good' universities can prove their roles in providing and supporting quality learning by extending their reach through online platforms (Lapadat 2007). At times, such claims might be readily justified by those whose choices reflect strong awareness and systematic pursuit of particular learning approaches. It is likely, however, that choices are often made using what might better be described as a learning methods 'recipes for nutrition' approach.

Through this 'recipes for nutrition' approach, academics might, for instance, begin their online materials development from institutional or even sector-wide expectations of establishing and providing a web-site for every subject using a technological platform already purchased and installed by the institution. (Such expectations are now common across at least Arts, Education, Science and Business faculties in Australian universities and elsewhere, including institutions where the overwhelming majority of students are enrolled in face to 
face classes (Hartman 2008; Nunan 2005)). Under these circumstances, there is little scope for academics to engage in educational philosophical debates. Neither is there ready opportunity for them to ask why online learning might be regarded as a positive expansion of the learning opportunities offered in their established teaching environments, or how the cognitive and intellectual fields in which they currently construct learning experiences might be advantaged. Instead, their focus of attention is constrained by technological platform boundaries and thus almost immediately concerns matters of content volume and materials characteristics, with the possibility that scaffolding might also be considered (Richards, Dooley and Lindner 2004). For the subject coordinator/convenor, it then becomes a question of what should be included, and how materials and learning activities should be structured, uploaded and assessed within the framework of the web platform chosen by the university.

Educational philosophy fails to hold a central position in the chains of decision-making and teaching/learning practices that ultimately proceed. In this context, it is not surprising that subject coordinators/convenors, lecturers and tutors adopt 'how does this platform work?', 'what can it do?', approaches to their online teaching. Much of their attention is taken with resolving issues of micro-pedagogy, such as determining the compromises they face in order to 'fit' content and approaches within the technological capacities of the university chosen platform. As Larsen and Vincent-Lancin (2006: 157) observe, after more than a decade of developments in online and electronic learning, 'there is no evidence to suggest that e-learning has yielded any radical pedagogic innovations.' Indeed, the extent to which online learning continues to present 'barriers' to 'effective, efficient and engaging learning' provides an ongoing site of extensive scholarship (Kim 2008: 188-192).

This paper argues that the absence of educational philosophy from online learning design and development within and among universities contributes to the lack of momentum in developing articulated online pedagogies/andragogies. In some respects, this is not especially problematic since it has hardly prevented or slowed the growth of a burgeoning online educational sector, including what might be perceived as a rapidly expanding online education business sector (Lapadat 2007). Yet, in other respects, it seems deeply problematic, suggesting that early efforts to achieve an understanding of the impacts and importance of online learning contexts within their broader social and political knowledge networks and authoritative contexts have stalled. The growth of online learning environments, platforms, objects, subjects of study and their various resources and manifestations has not been matched by the development of online pedagogy. In the rapid expansion of online and multimodal university education, pedagogic considerations have tended to follow more slowly than rates of technological adoption and expansion in the range of courses and subjects delivered (Woodman, Milankovic-Atkinson, Sadler and Murphy 2002:154). The first wave of online and electronic delivery led to the realization among those concerned with pedagogic implications presented by new technologies and their capacities to support flexible learning, that 'it is not new pedagogies that we need, but new ways of providing existing pedagogy efficiently and flexibly' (Mayes 2002:17). This quest for efficiency may well have contributed to ongoing under-attention to educational philosophy since pedagogy tends to lead quite directly to design issues in the development of online learning materials.

An additional part of the explanation for the absence of educational philosophy from online learning design and curriculum development derives from the processes whereby online learning has not only become part of the university level educational sector but in many instances has come to be the dominant educational mode (Lapadat 2007; Goodyear and Ellis 
2008). As university policy makers have taken institutional decisions to purchase online delivery systems or learning platforms, they have also established new expectations that academics will use them. Academics, who were already pressed for time in meeting shifting research targets and teaching diverse student cohorts, then found themselves needing to quickly learn how to use a range of new technologies that suddenly formed part of their regular teaching environments (Stephenson 2002; Brabazon 2007). It is hardly surprising that these staff proceeded from positions of 'how does it work?', 'what can it do?' questions in framing their decisions about how, rather than whether or why they would utilise online technologies. It is easy to understand their desire for efficiency in meeting this additional layer of complexity and its associated new imperatives.

It is also hardly surprising that early adopters of new technologies have largely set the tone for subsequent developments in online teaching (Kanuka 2002; Bates 2000; Hartman 2008). Their early 'successes' in employing new technologies to enable and support online discussions and content delivery have produced new baselines that make it almost impossible for academics to now question the merits of online learning as an educational enterprise. The primacy of 'how to' approaches has, from the outset, shaped the range and scope of online teaching and content and therefore also the learning experiences offered to students. It has also shaped the range and scope of related scholarship, such that asking 'how to' questions concerning platform or learning object functionality have become acquainted with demonstrations of competence, whilst asking 'why?' or 'who benefits?' amount to educational heresy. At the very least, these academics are all too readily identified as 'resistors' to innovation, reluctant participants who lag behind others in the 'new era' of university education (Mayes 2002; Hartman 2008; Moore, Fowler and Watson 2007).

This paper arose from a set of shared experiences as a small group of academics were brought together to explore and examine the adoption, maintenance and design of online learning environments within the School of Humanities, Communications and Social Sciences at Monash University, Gippsland Campus. The purpose of this group was to explore diverse approaches to incorporating online learning tools into distance education practices with a view to finding common ground that might support a school wide template for subject websites. It brought us the opportunity to work with colleagues from other liberal arts disciplines with a view, ultimately, to develop a group research and practice project. The overarching aims entailed enhancing our adoption and uses of technologies with particular attention to distance education. It is unsurprising that our group began with a 'how to' approach, perceiving online learning platforms and tools as central to expanding our capacities to provide and promote quality distance education.

In the context of the above discussion it is also unsurprising that our group readily agreed that online technologies could be helpful to students in acquiring and refining their skills and knowledge, yet differences were expressed regarding our primary motivations for interest in these issues. Over several meetings, our discussions spiralled, ranging from issues concerning platform capabilities to issues of cognitive and professional attributes and comportment, to matters of educational infrastructure. In structuring and perceiving our roles within the project in these ways, we revealed some implicit assumptions concerning the nature, structure and aims of learning that were embedded within our established online teaching practices and materials. In summary, we identified a pre-knowledge, pre-adoption 'ladder' of decision-making that impacted upon the design, development and implementation of academic adoption of online learning platforms. 
The decision making pyramid that follows tellingly shows the relative emphases of our discussions.

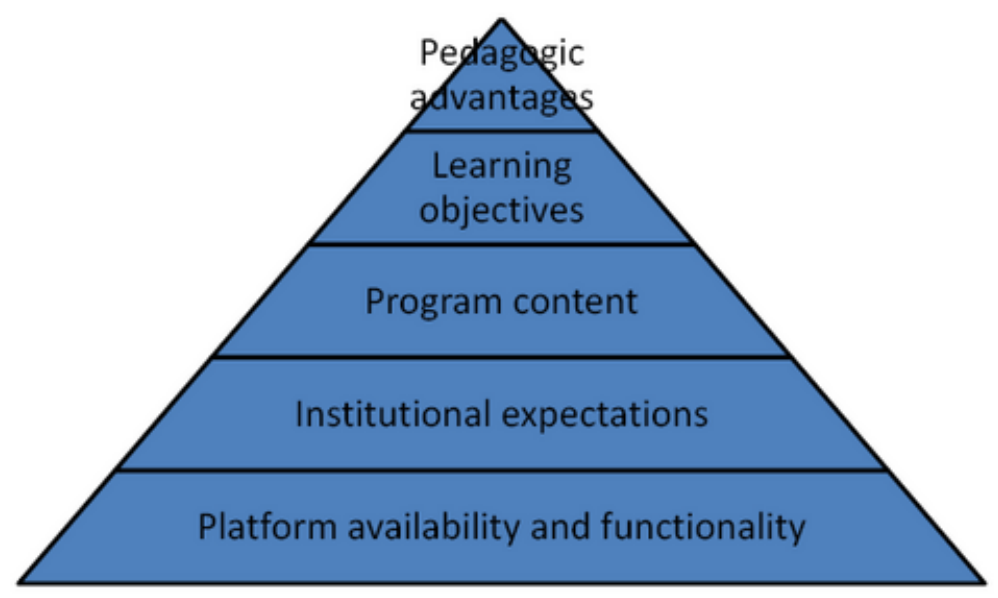

Figure 1.1: Online Learning Decision Pyramid

The first step in this ladder entailed the matter of which technologies could be used (policy and platform adoption issues), followed by the purposes for which they might be utilised (design and delivery purpose issues). These policy and platform issues concerned the availability, accessibility and ease of use of specific learning tools (materials content and learning tools match issues), matters of task, maintenance and responsibilities distribution (soft infrastructure requirements and expectations). In summary, we were concerned with:

- What's available?

- What's required?

- Who provides it?

- What can it do?

- How does its function correspond with content?

- How does its function correspond with learning objectives?

Our discussions also canvassed the question of academic workloads volumes and distributions, as well as our competencies in utilising the forms of technology and their specific functional characteristics, both within the face to face classroom and in support of online learning, especially for distance education students. Third, there was the question of why we believed that online learning environments might be beneficial to learning. Our reasons included the volume of information that students might gain ready access to, ready communication between staff and students, as well as among students and the creation of peer learning environments comprising communities of inquiry formed through shared problem-solving experiences. Underpinning all of the above, and revealed through these discussions were our views on educational philosophy, specifically concerning the value, nature and importance of university education and our own fields of interest and scholarship in particular.

These issues of pedagogic scope and educational philosophy were thrown into stark relief during a group meeting when one of our members indicated that he had begun to experiment 
with Wikis. Specifically, he outlined the production of a group assessment task wherein students constructed a group 'essay' by utilising a wiki. Some of us responded with excitement at the peer learning environment dimension, noting the manner in which collaborative learning might occur. Others were interested in the functional attributes and accessibility issues, perceiving the adoption of online technologies to be indicative of his commitment to supporting students' attainment of learning goals. The response of the lecturer to questions raised by other academics in the group project provided some surprise: 'It gives me less marking'. For him, the advantages of the Wiki were that he could reduce the number of essays submitted for marking and also support his claim to promotion as an innovative teacher. He was using an online platform that he could argue extended the suite of online tools utilised in teaching at this university - and this would constitute evidence of innovative teaching. By asking students to produce a collaborative essay utilising a wiki, our colleague aimed to considerably reduce his marking load since each wiki-based essay would be produced by groups of three to five students. He added that if students found the wiki experience useful, that would be a bonus.

We found this conversation disturbing. At one level we empathised with and were attracted by the notion of reducing our workloads by adopting a technological means to lessen our marking load. We were, however, ambivalent about reducing our opportunities to engage directly with individual distance education students, and to provide them with detailed feedback on their learning progress. On the other hand, we recognised the opportunities for students to create a community of learning with their peers. Yet we also perceived our colleague as displaying low regard for the nature and volume of student learning and upon reflection, considered his desire to reduce marking as reflecting a seemingly low regard for the transformational aspects of education. Online learning, from this perspective, apparently implied student-directed learning, but with minimal support and little regard for the need to scaffold learning in establishing a community of inquiry within which academics participated in an ongoing learning relationship with students.

Furthermore, we perceived our colleague as displaying a lack of respect for the individual study habits, learning styles, and educational motivations of students. We were unable to reconcile our colleague's approach to the use of wikis as an online learning platform with our own teaching approaches and philosophies of education. However, we were impressed with his ability to creatively utilise a readily available online platform in teaching both on campus and distance education students. Further discussion revealed that his wiki adoption supported a student-centred learning approach and his efforts towards explicating links between learning objectives and assessment tasks were admirable. Nonetheless, we remained uncomfortable with his overall approach. Upon reflection, we realised that we were struggling in the 'broken middle' between philosophy and practice trying to comprehend how the torn halves of educational philosophy and online teaching approaches and practices were related to teacher motivation and platform adoption in a high workload university environment.

Later we pondered the extent to which our initial personal reactions had been influenced by feeling that our own online teaching efforts might reflect a paucity of technological creativity alongside the innovative approach pursued by our colleague. We double-checked tendencies to be critical of his efforts because of perceived weaknesses and vulnerabilities in our own. We challenged each other's motivations and wondered whether we had revealed personal resistances to the changes brought about by web-based learning technologies, although we have both worked extensively with online learning platforms since they were 
first purchased by our university. We did not wish to develop and assert unreasoned or unwarranted criticisms of technological innovation, and yet we remained uneasy. The 'broken middle' was proving a difficult place to inhabit. We tried to avoid favouring one side or the other of the educational philosophy-online education dualism, attempting to maintain a speculative approach to thinking about the tenuous relationship between philosophy and educational practice.

This discomfort was heightened when our colleague proclaimed at a subsequent project meeting that 'all it takes to make online learning successful, is a better understanding among academics of the platforms they're using'. We wondered whether developing a fuller knowledge of the functional capacities of the university web platform (and our abilities to work with it) might open our eyes to new educational possibilities. We questioned whether we ought to more fully anticipate ways in which increasingly sophisticated software programs might create exciting new ways to connect with students and collaborate with them in experiential learning through communities of inquiry.

Some researchers and practitioners argue that understanding how online platforms work will enable teachers to better convey their educational philosophies, targeting their efforts to create effective online curriculum and learning relationships (Turoff, Discenza and Howard 2004; Ghaoui 2004; Palloff and Pratt 2007; Goodyear and Ellis 2008). Yet, if in practice, understanding how online platforms work enables teachers to work more easily within an online environment it will not necessarily lead to positive learning experiences for students, and neither will it ensure that teachers create conducive learning environments. It is important to better understand the capacities and functional characteristics of learning platforms because they frame the scope of curriculum delivery - and the relationships that can be sustained (and nurtured) within online learning environments (Goodyear and Ellis 2008; Hartman 2008; Palloff and Pratt 2007). What disturbed us was the functional approach expressed by our colleague - the platform does this, supports this, works in this way, therefore we expect students to learn in this way.

We concluded that although it is important for teaching staff to understand the functional capabilities of the online platforms utilised in their teaching (for a host of reasons, including workload management, ensuring student access to content and so on), functionality is by no means at the heart of ensuring effective or meaningful online learning (Kim 2008). Attaining some degree of comfort in reaching this point in our discussions, we remained unsettled as we speculated about the existence of a 'heart' of online learning. On the one hand, we remained acutely aware of the importance of understanding and utilising appropriate pedagogical design and learning approaches in online environments, especially in recognising key 'discursive elements' in shaping learning relationships (Lapadat 2007: 64). On the other hand, we remained equally aware of the manner in which our institutional settings influenced the forms of knowledge, ethical comportment and social values that we incorporated into our educational philosophies (Tubbs 2005; Moore, Fowler and Watson 2007; Stacey and Wiesenberg 2007).

University level drivers of technological adoption are influenced by 'market-share' imperatives, including a pressing need to decrease the costs incurred in providing paper-based learning resources, especially to distance education students (Williams, Paprock and Covington 1999; Nunan 2005). Sometimes, the institution is motivated by higher level government quality assurance imperatives (Chao, Saj and Tessler 2006; Reid 2005). Additional motivations arise from the range of principles that underpin broadening accessibility to higher education 
through enhanced course and curriculum flexibility (Palloff and Pratt 2007; Hall, Gordon and Black 2000). Adopting new technologies in university education can also be motivated by aspirations of reducing the relatively high attrition and incompletion rates that characterise distance education cohorts (Simpson 2003).

Spiralling around in this liminal space, the 'broken middle' between philosophy and education, we found ourselves again speculating on arguments asserting that understanding the interface created by online learning platforms, and/or learning tools within them, will enable teachers to progress their understandings of online pedagogy. Resisting the urge to take one side or the other we realised that each of these sets of arguments misses the point that learning occurs through relationships (and that relationships persist as central sites of effective learning within distance education cohorts). When students acquire new knowledge or skills, they also form new relationships between themselves and others, including their broader communities and the breadth/extent of knowledge within which they exist and associate (Jordan, Carlile and Stack 2008).

Connectedness is important to successful learning, especially among off campus students because of the relationships that underpin it. In the context of meaningful learning, connectedness coincides with 'layered belonging' which makes the formation of communities of inquiry especially important in online learning contexts (Woodman, Milankovich, Atkinson, Sadler and Murphy 2002; Turoff, Discenza and Howard 2004). This presents learners, teachers and course related policy-makers with responsibilities to ensure that layered belonging becomes a central feature of course pathways and teaching opportunities. Such connectedness begins with policy decisions and actions that commence with institutional procedures and extends into the functional characteristics of online learning platforms. What students learn is impacted by how they learn through the relationships that comprise their learning environments. Hence, we can perceive that the purpose of learning and the mode of learning or nature of learning experiences form complementary design imperatives. 


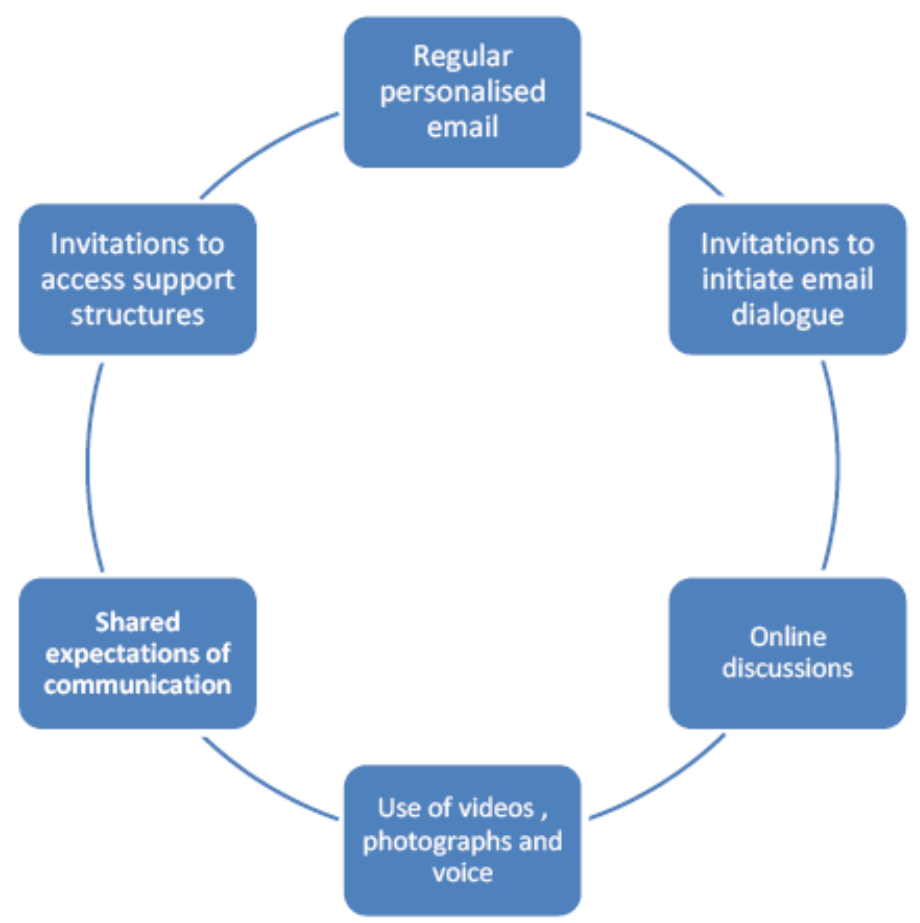

Figure 2: Creating a Connected Online Learning Environment

Ensuring that effective learning environments are created requires teachers to engage with fundamental questions concerning the nature and roles of values in shaping specific learning environments, establishing scope, structure and logic within courses and the curriculum-focused relationships through which learning proceeds. In online learning, asynchronous discussion groups can provide opportunities for students to integrate their learning experiences through social interactions. For many students, the value of such learning is enhanced by explicit affirmation, especially when it is identified with articulated learning objectives. Online learning platforms can provide for teacher feedback and iterative knowledge acquisition processes, enabling clarification, application and reflection throughout learning cycles (Edmondson 2009; Goodyear and Ellis 2008; Palloff and Pratt 2007; Lapadat 2007). Utilizing discussion groups in this manner can build motivation, achievement and connectedness to support successful off campus learning (Edmondson 2008).

Developing and maintaining supportive connectedness relies upon the creation of learning contexts and content materials that match students' diverse circumstances and learning needs (Brabazon 2007; Lapadat 2007; Magoulas and Chen 2006). This connectedness requires shared expectations of specific learning outcomes, and learning and communications processes between teaching staff and students. Connectedness therefore relies upon ongoing, regular and predictable support which might be effectively sustained through appropriate pedagogic design of learning materials. After all, the primary advantage of online learning contexts is the notion of autonomy (La Pointe and Reisetter 2008). 
At our university, at the end of each semester students are asked to complete an online evaluation of each of the subjects they have studied in that semester. The survey instrument utilised assumes the ongoing existence of online learning, tending to seek confirmation of the positive contributions of online learning experiences. For instance, students are asked to consider the extent of flexibility provided by online learning. They are asked whether online materials encourage their study efforts, but they are not asked to compare online learning materials, content, or experiences to other learning modes. In short, students are given little opportunity to reject or provide negative comment concerning their online learning experiences.

For our colleague, the functional attributes of online learning technologies determine their utility, and to some extent, also their pedagogical purpose. For us, the question of what new technologies can do remains largely irrelevant until we understand whether and how adopting them might positively contribute to an overall learning context. For us, it is less a matter of particular skills and more a matter of the manner in which technologies, including online learning platforms, support the relational dimensions of learning.

Resisting the satisfaction of the certainties suggested above, we speculate that it may well be precisely because many recent developments in interactive communications technologies afford new relational opportunities that has led to their rapid adoption in online and blended learning. This does not mean, however, that university lecturers and tutors understand their particular roles in framing new learning contexts, structuring learning environments, or that they wish to utilise new technologies to support particular learning relationships. Neither does it mean that the learning platforms and ICTs purchased by universities for use in online teaching necessarily effectively support the range and forms of relationships that matter most for meaningful learning. Nonetheless, it is readily apparent that many young people are adept at building interpersonal relationships online - and universities might be justified in presuming that these skills are readily transferable to establishing and maintaining effective online learning relationships (Kim 2008: 192). It is also important, however, to bear in mind some key differences between the interpersonal skills associated with social networking and those associated with learning relationships, although the skills required for accessing their respective online tools and platforms are similar.

If universities perceive the need to 'keep pace' with the technological skills of young people by utilising online learning platforms, then the nature of the relationships that students form and the appropriateness of these relationships for effective learning need to be carefully considered. Social networking phenomena could be said to engage young people within the experiences and knowledge bases of their demographic group, while academic learning requires different forms of engagement and relationship building from those developed through social networking. Recent debates concerning young online users as 'digital natives' compared with older users as 'digital immigrants' reflect the importance of these issues (Prensky 2001). Interestingly, aspects of 'trust' related issues can be identified as common sources of impact upon learning and technology use patterns (Smith 2008; Goodyear and Ellis 2008; Magoulas and Chen 2006; Moore, Fowler and Watson 2007).

Adopting new technologies might contribute to opportunities for students to engage in flexible learning in a broader social context where government and university rhetoric of lifelong learning opportunities abound. However, these aspects of the broader social context of online learning must be placed alongside expectations that many people will change their careers at least three times during their working lives and the likelihood that university stu- 
dents will increase in diversity as a result. This is an especially important consideration for distance education since student heterogeneity among off campus learners is already pronounced (Hudson 2002; Williams, Paprock and Covington 1999; Magoulas and Chen 2006; LaPointe and Reisetter 2008). Online learning platforms therefore need to enhance learning relationships and must be soundly supported by educational philosophies that take account of these broader social realities and emerging patterns.

Meaningful education is not just about achieving behavioural objectives. Learning also entails altering and enhancing the activities and processes of the mind (Kim 2008; Boud, Cohen and Walker 1997; Kolb 1984). These two statements encapsulate tensions between the increasing diversity of our university students and a homogeneity assumed by on-line platforms. Interestingly, an inverse relationship is apparent in our colleague's comment that the way the platform works determines the way we expect students to learn. By assuming homogeneity, the technological platform requires it of students.

Off campus delivery modes render differences between students invisible resulting in homogenisation that can prove unhelpful to learning outcomes and satisfaction levels (Edmondson 2009; LaPointe and Reisetter 2008). While this 'peculiar mix of invisibility and assumed similarity' frees students from the pressures of social conformity in face to face classrooms, it creates challenges for educators seeking to recognise and respond to increasing student diversity within online teaching environments. Students cannot know how best to learn without interaction, supported identification of learning goals and provision of content knowledge. It is self-evidently true that technology (and paper based modes of presentation) alter the learning environments of students, but these do not, of themselves, necessarily alter the nature of student learning.

The experience of trying to remain in the uncomfortable space of the 'broken middle' of our discussion and speculating rather than progressing in a linear fashion from problem to resolution enables new ideas and connections to enter into this complex and multifaceted discussion space. The notion of invisibility leads us to consider differences between students who are silent in a face to face classroom, yet are able to convey their malaise or offer challenges through their body language, and those students, often described pejoratively as on-line 'lurkers', who do not 'visibly' connect to the online learning community through discussion group postings. Effective learning occurs through discussions when one can observe participants engaging in 'the art of co-operative thinking aloud' (Killen 1998: 26). Mutual speculation, deliberation and shared problem solving efforts can support diverse and rich learning experiences. A spectral image of 'invisible' online students emerges, whose reasons for 'lurking' rather than joining the learning community are difficult to understand and respond to. Is their lurking to be recognised as a deliberate statement of difference, an 'invisible' rejection of the expectations of an on-line learning platform? These ideas bring a new facet to this discursive exploration.

Lurkers are commonly considered to lack the confidence to post; to be naturally passive, like television viewers; to be abusers of the common good or 'free riders', or are wary of the persistence of messages (Nonnecke and Preece 2001). Assuming that on-line users were also at times lurkers, Nonnecke and Preece (2001) interviewed users about their online behaviour. Their research suggests that lurking is a strategic and idiosyncratic activity engaged in for a range of personal and other needs. Fear of the persistence over time of online communications was a strong deterrent to posting. 
In an academic setting, fear may well be a reason for lurking as students are required to engage in significant risk-taking by immersing themselves in intellectual arguments, analysis and conceptualising new ideas and linkages. Taking these risks requires learning environments that engender supportive connectedness among students. Achieving this goal requires utilising systematic encouragement and supporting students as they 'play around' by experimenting with their learning and 'learning from their learning' (Edmondson 2007; Richards, Dooley and Lindner 2004; Bruner 1999). Nonnecke and Preece (2001) urge a greater focus on connectedness in online environments, asserting that any improvements aimed at engaging lurkers will improve the online environment for all users. Nonetheless, lurking does not necessarily create distance or prevent connectedness between lurkers and more overtly active discussion group participants.

LaPointe and Reisetter (2008) provide a useful glimpse of students' perspectives of online learning. They surveyed graduate students enrolled in Masters programs to assess the importance of on-line communities for their learning. The researchers supported the assertion that focussing on student diversity is equally important in online and classroom learning environments. The diversity revealed by their survey included some students who questioned the importance of creating a community of learners for deep learning to occur. This group of students valued highly connections with their lecturers but did not value the online community. They did not want to know their fellow students' views, valuing instead their own ability to think independently.

These findings are consistent with others who have also found that peer online discussion groups worked for some students but not others (Menchaca and Bekele 2008). Common to these 'mixed' findings is the broader contextual importance of meaningful connectedness between students and the institution, faculty, course administrators and teaching staff alongside student autonomy (Magoulas and Chen 2006; Edmondson 2009; Palloff and Pratt 2007). La Pointe and Reisetter (2008) conclude by emphasising the need for on-line course designers, to recognise the diversity of learners' expectations, to support deep and durable learning. This will require those who design and purchase online learning platforms and those who adopt them in teaching and learning to reframe their understanding of online communication processes. These recommendations support a greater focus on educational philosophy and pedagogies in considering what online platforms can do.

Our speculative discussion of the 'broken middle' of the relationship between educational philosophy and on-line teaching approaches has brought us to a paradox. Technology increases the possibilities of connectedness of diverse peoples whilst the technological platforms constrain the ways we connect in an educational setting. Market and credentials related imperatives drive universities to embrace on-line education. These and other factors (some of which have been discussed in this paper) contrive to produce an over-sensitivity to the importance of technological platforms themselves, rather than permitting educational philosophy to drive approaches to and use of online learning. As teaching academics we remain in the uncomfortable and challenging space we call the 'broken middle' between philosophy and educational practice, neither fully embracing nor totally resisting technologically based teaching, preferring to focus upon the sites and forms of relationships that are made possible. Institutions can play vital roles in supporting the mucky business whereby as academics we continue to re-negotiate the philosophical and technological challenges of online learning, and re-frame both the relational dimensions of teaching/learning and their adoption of online learning platforms. 


\section{References}

Alexander, S. and Boud, D. (2002) 'Learners still learn from experience when online', in Stephenson, J. (ed.) Teaching and Learning Online: Pedagogies for New Technologies, Kogan Page, London.

Bates, A. W. (2000) Managing Technological Change: Strategies for Colleges and University Leaders, Jossey-Bass, San Francisco.

Bell, M., Bush, D. F., Nicholson, P., O'Brien, D. and Tran, T.(2002) Universities Online: A Survey of Online Education and Services in Australia, Occasional Paper Series, Higher Education Group, Commonwealth Department of Education, Science and Training.

Boettcher, J. V. (2004) 'Design Levels for Distance and Online Learning', in Howard, C. Schenk, K., and Discenza, R. (eds.), Distance Learning and University Effectiveness: changing educational paradigms for online learning, Information Science Publishing, Hershey, London, Melbourne and Singapore.

Bok, D. (2006) Our Underachieving Colleges: A Candid Look at How Much Students Learn and Why They Should Be Learning More, Princeton University Press, Princeton.

Bowles, M. S., (2004), Relearning to E-Learn: Strategies for electronic learning and knowledge, Melbourne University Press, Melbourne.

Brabazon, T. (2007) The University of Google: education in the (post) information age, Ashgate, Aldershot.

Bruner, J. (1999) 'Folk Pedagogies', in Leach, J. and Moon, B. (eds.), Learners and Pedagogy Open University Press, London.

Chao, T., Saj, T., and Tessler, F. (2006) 'Establishing a Quality Review for Online Courses', EDUCAUSE Quarterly, Number 3, 32-39.

Coomey, M. and Stephenson, J. (2002) 'Online learning: it is all about dialogue, involvement, support and control - according to the research', in Stephenson, J. (ed.), Teaching and Learning Online: Pedagogies for New Technologies, Kogan Page, London.

Duffy, T. M. and Kirkley, J. R. (2004) 'Learning Theory and Pedagogy Applied in Distance Learning: The Case of Cardean University' in Duffy, T. M. and Kirkley, J. R., Learner-Centred Theory and Practice in Distance Education: Cases from Higher Education, Lawrence Erlbaum Associates, Mahwah, N.J. and London.

Edmondson, B. (2007) 'Making Flexible Delivery Meaningful', International Journal of Learning, Volume 14, Number 14, 9-18.

Edmondson, B. (2008) 'Confronting the Pedagogical Challenges of Online Asynchronous Discussion Groups', International Journal of Learning, Volume14, Number 12, 101-107.

Edmondson, B. (2009) 'Making it personal: the value of connectedness in off campus learning', Collected Wisdom: symposium on distance education, OCLC Monash University.

Ghaoui, C. (2004) E-Education Applications: Human Factors and Innovative Approaches, Information Science Publishing, Hershey, London, Melbourne and Singapore.

Goodyear, P. and Ellis, R. A. (2008) 'University students' approaches to learning: rethinking the place of technology', Distance Education, Volume 29, Number 2, August, 141-152.

Hall, L., Gordon, A., and Black, P. (2000), 'Supporting Flexible Learning Over the Net' in Orange G. and Hobbs, D. (eds.), International Perspectives on Tele-Education and Virtual Learning Environments, Ashgate, Aldershot.

Hartman, J. L. (2008) 'Moving Teaching and Learning with Technology from Adoption to Transformation', EDUCAUSE Review, November/December, 24-25.

Hase, S. and Ellis, A. (2002) 'Problems with online learning are systemic, not technical', in Stephenson, J. (ed.), Teaching and Learning Online: Pedagogies for New Technologies, Kogan Page, London.

Hudson, B., (2002), 'The Jungle Syndrome: Some Perils and Pleasures of Learning Without Walls', in Rudestam, K. E., and Schoenholtz-Read, J. (eds.), Handbook of Online Learning: Innov- 
ations in Higher Education and Corporate Training, Sage Publications, Thousand Oaks, CA.

Jordan, A., Carlile, O. and Stack, A. (2008) Approaches to Learning: a guide for teachers, McGraw Hill and Open University Press, Maidenhead and New York.

Kanuka, H. (2002), 'A Principled Approach to Facilitating Distance Education: The Internet, Higher Education and Higher Levels of Learning', Journal of Distance Education, Vol. 17, No. 2.

Killen, R. (1998) Effective Teaching Strategies: lessons from Research and Practice, Social Science Press, Katoomba $2^{\text {nd }}$ edition.

Kim, C. (2008) 'Using email to enable $\mathrm{e}^{3}$ (effective, efficient and engaging) learning', Distance Education, Volume 29, Number 2, August, 187-198.

Kolb, D. (1984), Experiential Learning, Prentice Hall, Englewood Cliffs, NJ.

Lapadat, J.C. (2007) 'Discourse Devices used to Establish Community, Increase Coherence, and Negotiate Agreement in an Online University Course', Journal of Distance Education Volume 21, Number 3, Spring/Summer, 59-92.

LaPointe, L. and Reisetter, M. (2008) 'Belonging Online: Students' Perceptions of the Value and Efficacy of an Online Learning Community', International Journal on E-Learning 7(4), 641665 .

Larsen, K. and Vincent-Lancin, S. (2006) 'The Impact of ICT on Tertiary Education: Advances and Promises', in Kahin, B. and Foray, D. (eds.), Advancing Knowledge and the Knowledge Economy, MIT Press, Massachusetts and London, England.

Magoulas, G. D. and Chen, S. Y. (eds.) (2006) Advances in Web-Based Education: Personalized Learning Environments, Information Science Publishing, Hershey, London, Singapore and Melbourne.

Mayes, T. (2002), 'Learning technology and learning relationships', in Stephenson, J. (ed.), Teaching \& Learning Online: Pedagogies for New Technologies, Kogan Page, London.

Maxcy, S. (1978) Educational Philosophy For The Future, University Press of America, Washington DC.

Menchaca, M. P. and Bekele, T. A. (2008) 'Learner and instructor identified success factors in distance education', Distance Education, Volume 29, Number 3, 231-252.

Moore, A. H., Fowler, S. B. and Watson, C. E. (2007) 'Active Learning and Technology: Designing Change for Faculty, Students and Institutions, EDUCAUSE Review September/October,4360.

Nonnecke, B. and Preece, J. (2001) 'Why Lurkers Lurk', Americas Conference on Information Systems, 2001http://www.cis.uoguelph.ca/ nonnecke/research/whylurk.pdf Accessed 19 July, 2009.

Nunan, T. (2005) 'Markets, Distance Education, and Australian Higher Education', The International Review of Research in Open and Distance Learning, Volume 6, Number 1.

Owen, R. S. and Aworuwa, B. (2004), 'Precursors to Web-Based Methodologies: Lessons We Can Learn from Teaching Machines, Automatic Tutoring Devices and Learning Hierarchies', in Ghaoi, C. (ed.), E-Education Applications: Human Factors and Innovative Approaches, Information Science Publishing, Hershey, London, Melbourne and Singapore.

Palloff, R. M. and Pratt, K. (2007) Building Online Learning communities; effective strategies for the virtual classroom, John Wiley and Sons, San Francisco, $2^{\text {nd }}$ edition.

Parchoma, G. (2003), 'Learner-Centred Instructional Design and Development: Two Examples of Success', Journal of Distance Education, Vol. 18, No. 2.

Prensky, M. (2001) 'Digital Natives, Digital Immigrants', On the Horizon, Vol. 9, Number 5, October.

Richards, L., Dooley, K. E. and Lindner, J. R. (2004), 'Online Course Design Principles', in Howard, C., Schenk, K., and Discenza, R. (eds.), Distance Learning and University Effectiveness: Changing Educational Paradigms for Online Learning, Information Science Publishing, Hershey, London, Melbourne and Singapore.

Reid. I. C. (2005) 'Quality Assurance, Open and Distance Learning, and Australian Universities', The International Review of Research in Open and Distance Learning, Volume 6, Number 1. 
Simpson, O. (2002) Supporting Students in Online, Open and Distance Learning, $2^{\text {nd }}$ edition, Kogan Page, London and Sterling.

Simpson, O. (2003) Student Retention in Online, Open and Distance Learning, Kogan Page, London.

Smith, R. O. (2008) 'The Paradox of Trust in Online Collaborative Groups, Distance Education Volume 29, Number 3. November, 325-340.

Stacey, E. , and Wiesenberg, F. (2007) 'A Study of Face-to-Face and Online Teaching Philosophies in Canada and Australia', Journal of Distance Education, Volume 22, Number 1, $19-40$.

Stephenson, J. (2002), 'Introduction' in Stephenson, J. (ed.), Teaching \& Learning Online: Pedagogies for New Technologies, Kogan Page, London.

Turoff, M., Discenza, R. and Howard, C. (2004), 'How Distance Programs will Affect Students, Courses, Faculty and Institutional Futures', in Howard, C., Schenk, K., and Discenza, R. (eds.), Distance Learning and University Effectiveness: Changing Educational Paradigms for Online Learning, Information Science Publishing, Hershey, London, Melbourne and Singapore.

Tubbs, N. (2005) 'Philosophy of the Teacher', Journal of Philosophy of Education, Vol 39; Issue 2 Special Issue.

Williams, M. L., Paprock, K. and Covington, B. (1999), Distance Learning: The Essential Guide, Sage Publications, Thousand Oaks, London and New Delhi.

Woodman, M., Milankovic-Atkinson, M., Sadler, C. and Murphy, A. (2002), 'From conventional to distance education: adopting a pedagogy and managing the transformation' in Stephenson, J. (ed.), Teaching \& Learning Online: Pedagogies for New Technologies, Kogan Page, London.

\section{About the Authors}

Dr. Beth Edmondson

I teach in a variety of areas, including International Relations, Australian Politics and Policy Studies and Gender Studies. I have utilised a variety of online learning options in working with off campus students in my own subjects and coordinated a major university initiative in designing and developing interactive e-learning materials in a diverse range of Arts disciplines, including Chinese and Japanese languages and content based social science subjects. I remain interested in the importance of design, opportunities for flexible active student centred learning and pedagogical application in elearning.

Debra Manning

Monash University Gippsland Campus, Australia 
Copyright of International Journal of Learning is the property of Common Ground Publishing and its content may not be copied or emailed to multiple sites or posted to a listserv without the copyright holder's express written permission. However, users may print, download, or email articles for individual use. 